\title{
Penerapan Dasar Akrual pada Akuntansi Lembaga Keuangan Syariah
}

\author{
Enriko Tedja Sukmana, MSI \\ Program Studi Perbankan Syariah, IAIN Palangka Raya \\ Email : enriko.tedja@gmail.com
}

\begin{abstract}
Abstrak
Penggunaan dasar akrual merupakan bentuk dari penerapan asumsi yang ada dalam penyusunan laporan keuangan. Model dasar akrual mengakui pendapatan dan biaya sebagai sesuai yang dimiliki meskipun belum diterima maupun dikeluarkan secara kas. Seperti halnya akuntansi pada umumnya, asumsi dasar pada akuntansi syariah juga mempergunakan dasar akrual, hal tersebut ditunjukkan pada perlakan akuntansi syariah dalam transaksi dengan akad syariah. Hal tersebut diatur pada ketentuan menyangkut penerapan akuntansi syariah pada lembaga keuangan syariah. Berdasarkan penerapan tersebut penggunaan dasar akrual terletak pada pengakuan keuntungan dari transaksi syariah. Pengakuan keuntungan transaksi sewa dan syirkah dilakukan terhadap keuntungan yang diperoleh dalam penyerahan aset non kas sebagai bagian dari kesepakatan. Sedangkan pada transaksi jual beli pengakuan keuntungan dilakukan saat serah terima barang dari lembaga keuangan syariah kepada pemesan sebagai pembeli. Pengakuan dasar akrual pada akad jual beli dengan pengakuan keuntungan di awal memiliki resiko yang besar saat piutang tidak tertagih. Untuk menghindari itu lembaga keuangan syariah yang sebaiknya menghindari pengakuan keuntungan di awal terhadap piutang murabahjah, dengan memilih alternatif metode pengakuan keuntungan lainnya.
\end{abstract}

Kata kunci : Dasar akrual, Akuntansi Lembaga Keuangan Syariah.

\begin{abstract}
The use of accrual basic is one of applying the assumptions contained in the preparation of financial statements. The accrual basic model recognizes income and expenses as recorded altought not yet received or issued in cash. Same with accounting in general, assumptions basic on sharia accounting also use accruals basic, it is shown in sharia accounting treatment in sharia transaction. The accrual basic reatment is arranged in the provisions of sharia accounting in Islamic financial institutions. Based on these provisions, the use of accrual basic done in the recognition of the benefits of sharia transactions. Recognition of profit lease and shirkah transactions is made to the profits derived in the transfer of non-cash assets as part of the agreement. Despite of that sale and purchase transactions recognition of profits made when the handover of goods from Islamic financial institutions to consumer. The treatment of accrual basic on the sale and purchase agreement with the recognition of early profits has a great risk when receivables are not collectible. To avoid that Islamic financial institutions should avoid early profits recognition of murabah\}ah receivables, by choosing alternative methods of recognition of other profits.
\end{abstract}

Key words : accrual basic, sharia financial institution accounting 


\section{Pendahuluan}

Akuntansi mengenal dua pendekatan dalam pencatatan transaksinya yaitu dasar akrual dan dasar kas. Melalui kedua pendekatan pencatatan tersebut dapat diketahui aliran keluar masuknya dana dalam sebuah entitas, meskipun terdapat perbedaan dalam waktu pengakuan dana tersebut tergantung kepada pendekatan yang dipergunakan. Akuntansi syariah sebagai sebuah sistem akuntansi yang dipergunakan oleh lembaga keuangan syariah juga menerapkan kedua jenis pendekatan pencatatan tersebut.

Lembaga keuangan syariah dalam mencatat transaksinya mempergunakan akuntansi syariah sebagai rujukan utama, seiring telah dibakukannya perlakukan akuntansi yang berdasarkan kepada akad yang dipergunakan. Setiap akad transaksi yang berbeda akan mempergunakan model perlakuan akuntansi yang berbeda-beda yang disesuaikan dengan jenis transaksinya seperti bagi hasil, jual beli, sewa-menyewa dan sebagainya. Perbedaan jenis transaksi yang dipergunakan dalam akad menjadikan perlakuan dalam akuntansi syariah memiliki akun yang bervariasi, meskipun dari satu sisi perbedaan tersebut hanyalah sebuah perbedaan penamaan. Semua itu dikarenakan dalam akuntansi syariah kerangka dasarnya sama dengan kerangka dasar dalam akuntansi pada umumnya, seperti penggunaan debet dan kredit, keseimbangan neraca, pendekatan dalam pencatatan, termasuk pada esensi utama akuntansinya yaitu persamaan dasar akuntansi yang tetap mempergunakan elemen aset, hutang, modal, pendapatan dan biaya.

Penggunaan pendekatan pencatatan yang diaplikasikan dalam akuntansi syariah disesuaikan dengan kondisi transaksi yang dilakukan, sehingga tidak semua transaksi dapat menggunakan pendekatan yang sama. Istilah tangguhan dalam akun keuntungan atau pendapatan merupakan bentuk penggunaan acrual basis dalam akuntansi syariah, yang merujuk kepada suatu kondisi dimana nilai kas yang masih ditangguhkan dan akan diterima pada masa yang akan datang. Hal tersebut dari sisi penerimaan pendapatan mengarah kepada pengakuan terhadap sesuatu yang belum dapat dipastikan keberadaannya, dan secara jauh akan berimplikasi kepada nilai bagi hasil yang harus ditunaikan.

1. Akuntansi syariah

Akuntansi syariah merupakan instrumen yang dipergunakan dalam kegiatan ekonomi, sebagai alat untuk menterjemahkan transaksi keuangan syariah ke dalam bentuk informasi keuangan yang dapat dipahami oleh semua pihak. Sesuai dengan definisi akuntansi pada umumnya bahwa akuntansi merupakan suatu sistem informasi yang mengidentifikasikan, mencatat, dan mengkomunikasikan peristiwa-peristiwa ekonomi dari suatu organisasi kepeda pengguna yang berkepentingan, ${ }^{1}$ dengan demikian fungsi akuntansi adalah sebagai ilmu yang dipergunakan untuk mengolah data-data transaksi menjadi sebuah informasi yang dapat dipergunakan oleh semua pihak yang membutuhkannya. Melihat dari fungsinya tersebut akuntansi syariah merupakan alat yang dipergunakan untuk menterjemahkan dan merangkum semua praktik transaksi keuangan syariah ke dalam bahasa yang dapat dimengerti secara general dalam bentuk laporan keuangan.

Keberadaan akuntansi syariah itu sendiri merupakan sebuah jawaban dari perkembangan ekonomi Islam yang semakin pesat bergerak maju menuju kejayaannya kembali. Perkembangan ekonomi Islam yang ada berimplikasi pada

1 Weygant, Jerry J., Kieso, Donal E., Kimmel, Paul D. 2005. Accounting Principles, terj. Ali Akbar Yulianto dkk. Jakarta : Salemba Empat. 
rutinitas traksaksi keuangan syariah, terutama yang dilakukan oleh lembagalembaga keuangan syariah. Sebagai pelaku utama kegiatan transaksi syariah tentulah, lembaga-lembaga tersebut memerlukan pedoman khusus yang mengatur transaksi yang mereka lakukan dari berbagai aspek pendekatan, dalam hal ini termasuk aspek pencatatan dan pelaporan (akuntansi).

Seiring kondisi yang ada tersebut, dibentuklah pedoman yang mengatur tentang perlakuan akuntansi syariah, di Indonesia pedoman tersebut diatur dalam Pernyataan Standar Akuntansi Keuangan Syariah atau yang dikenal PSAK Syariah. ${ }^{2}$ Pernyataan tersebut mengatur bagaimana perlakuan akuntansi untuk transaksitransaksi keuangan syariah yang dikenal memiliki klasifikasi tertentu dalam penggunaannya. Penggunaan transaksi syariah akan disesuaikan dengan jenis akad yang dipergunakan misal akad jual-beli, akad sewa, atau akad bagi hasil, ketiga akad tersebut memiliki perlakuan akuntansi yang tidak sama, meskipun perbedaan yang ada lebih pada penamaan akun yang disesuaikan dengan transaksi yang dipergunakan.

Perlakuan akuntansi syariah pada dasarnya tidak memiliki perbedaan yang signifikan dengan akuntansi yang ada, pada akuntansi syariah pola tetap menganut Persamaan Dasar Akuntansi dan mempergunakan double entry system ${ }^{3}$

2 Pada awalnya Pernyataan Standar Akuntansi Syariah hanya mengatur tentang Perbankan Syariah (PSAK no 59), namun seiring dengan perkembangan lembaga keuangan syariah non bank akhirnya dibentuk standar akuntansi syariah yang dapat dipergunakan oleh lembaga non bank (PSAK no 101-110).

3 Persamaan Dasar Akuntansi merupakan bagian fundamental dalam akuntansi yang menjadi dasar keseimbangan akuntansi yang terdiri atas Aset $=$ Kewajiban + Ekuitas Pemilik, kemudian double entry system (sistem pencatatan berpasangan) ditujukan untuk tetap menjaga keseimbangan persamaan dasar akuntansi seperti pada akuntansi pada umumnya. Perbedaan terdapat pada elemen tambahan dalam persamaan dasar akuntansi yang ada dengan adanya elemen dana syirkah temporer yang merupakan salah satu ciri ekonomi syariah dalam transaksi bagi hasil.

Perbedaan utama antara akuntansi syariah dengan akuntansi pada umumnya terletak kepada konsep nilai non materi yang dianut oleh akuntansi syariah . Meskipun dalam akuntansi saat ini telah mempergunakan banyak pendekatan dalam kajiannya seperti akuntansi sosial, akuntansi keprilakuan dan sebagainya, namun hal tersebut tetap menjadi sesuatu yang terpisah dari keilmuan akuntansi itu sendiri. Iwan Triyuwono menjelaskan bahwa akuntansi syariah berangkat dari perspektif Khalifatullah fi Ardh yang menjadi tujuan utama bagi setiap manusia, pertanggung jawaban yang dilakukan dalam akuntansi syariah tidak hanya berada dalam taraf materi namun juga pada aspek yang lebih mendalam pada aspek non materi yaitu pertanggung jawaban kepada Tuhan. $^{4}$

Iwan Triyuwono sendiri membagi akuntansi syariah pada dua aliran pemikiran yaitu akuntansi syariah filosofis teoritis dan akuntansi syariah praktis. ${ }^{5}$ Kedua aliran pemirikan ini melihat akuntansi syariah dari kedua sisi yang berbeda dan bertolak belakang namun saling melengkapi, akuntansi syariah filosofis teoritis mencoba melihat akuntansi dari sisi nilai-nilai dasar yang teranut di dalam pencatatan berbasis syariah, sedangkan akuntansi syariah praktis lebih

tersebut. Pada akuntansi syariah persamaan dasar akuntansinya ditambahkan elemen dana syirkah temporer sehingga komponennya yaitu terdiri atas aset = kewajiban + dana syirkah temporer + ekuitas pemilik.

4 Triyuwono, Iwan. 2012. Akuntansi Syariah Perspektif, Metodologi, dan Teori, Jakarta : PT. Raja Grafindo Persada, hal. 198.

5 Ibid., hal. 6. 
menekankan pada sisi kebutuhan praktis dari sebuah pencatatan bagi lembagalembaga keuangan syariah.

Akuntansi syariah praktis itu sendiri tertuang pada PSAK Syariah yang menjadi pedoman bagi setiap lembaga keuangan syariah atau lembaga keuangan yang menjalankan bisnis syariah, agar terdapat kesamaan dan kesesuaian bentuk laporan keuangan. Generalisasi ini dimaksudkan untuk mempermudah siapa pun yang ingin mendapatkan informasi dari laporan keuangan yang dihasilkan oleh lembaga keuangan, dengan adanya standar baku laporan keuangan, akan mempermudah akses bagi pihak berkepentingan untuk membandingkan antara satu laporan keuangan dengan laporan lainnya. Hal tersebut seusuai dengan empat karaketeristik kualitatif laporan keuangan yaitu pertama dapat dipahami dengan segera dan mudah informasi keuangan yang disampaikan, kedua relevan untuk memenuhi kebutuhan pengguna dalam proses pengambilan keputusan, ketiga bebas dari pengertian yang menyesatkan, kesalahan material, dan dapat diandalkan oleh penggunanya, dan keempat dapat dibandingkan informasinya antar periode maupun dibandingkan dengan informasi dari lembaga keuangan lainnya. ${ }^{6}$

Laporan keuangan yang ada pada akuntansi syariah setidaknya terdiri dari laporan posisi keuangan atau neraca, laporan laba rugi, laporan arus kas, laporan perubahan ekuitas, laporan sumber dan penggunaan dana zakat, laporan sumber dan penggunaan dana kebajikan, serta laporan rekonsiliasi pendapatan dan bagi hasil. Di antara unsur-unsur laporan tersebut, laporan dana zakat, dana kebajikan serta pendapatan dan bagi hasil merupakan ciri khas dari laporan keuangan

$6 \quad$ Nurhayati, Sri. Wasilah. 2013. Akuntansi Syariah di Indonesi. Jakarta : Salemba Empat. hal. 100-104.
Islam. Keberadaan unsur laporan tersebut terkait dengan bentuk dan jenis dana yang ada pada sistem keuangan syariah, pada akuntansi syariah terdapat pemisahan antara dana pada transaksi keuangan yang dilakukan dengan dana di luar transaksi keuangan yang dilakukan. Dana zakat dan dana kebajikan bukan merupakan dana yang dihasilkan atau diperoleh dari transaksi keuangan syariah serta memiliki alokasi distribusi yang berbeda, keduanya merupakan dana yang bersifat sosial dalam penggunaannya.

Laporan keuangan syariah memiliki dua asumsi dasar yang dipergunakannya dan tidak jauh berbeda dengan akuntansi pada umunya yaitu going concern dan acrual basis. Berdasarkan asumsi going concern menjelaskan laporan keuangan syariah disusun berdasarkan asumsi bahwa lembaga keuangan syariah akan menjalankan usahanya secara berkelanjutan dengan tidak menampak maksud untuk mengurang skala usahanya, sedangkan asumsi acrual basis menjelaskan bahwa kegiatan transaksi yang dilakukan oleh lembaga keuangan syariah tidak hanya melibatkan penerimaan dan pengeluaran kas pada transaksi masa lalu tetapi juga melibatkan kewajiban pembayaran dan pendapatan penerimaan yang merepresentasikan kas pada masa yang akan datang. ${ }^{7}$ Kedua asumsi tersebut merupakan landasan asumsi yang dipergunakan dalam penyusunan laporan keuangan, dengan asumsi tersbut menunjukan dapat keberlangsungan usaha yang dijalankan oleh lembaga keuangan syariah.

\section{Pembahasan}

\section{Asumsi Dasar Pencatatan Akuntansi}

Salman, Kautsar Riza. 2012. Akuntansi Perbankan Syariah berbasis PSAK Syariah. Padang : Akademia. hal. 101. 
Laporan keuangan memiliki tujuan untuk memberikan informasi keuangan dari entitas penyusun bagi pihak berkepentingan sebagai bahan pertimbangan bagi pihakpihak teresbut dalam mengambil keputusan terkait kebijakan maupun keputusan mereka terhadap entitas. Pihak yang berkepentingan baik secara intern maupun ekstern akan membuat keputusan yang berbeda-beda melalui informasi keuangan yang diperolehnya sesuai dengan kebutuhan pihak-pihak tersebut, di mana keputusan tersebut secara langsung maupun tidak langsung akan berpengaruh terhadap keberadaan entitas penyusun laporan.

Laporan keuangan disusun

berdasarkan asumsi yang dibangun sebelumnya, yaitu going concern (kelangsungan usaha) dan acrual basis (basis akrual). Keduannya merupakan asumsi yang harus ditunjukkan dalam penyususnan laporan keuangan sehingga pihak pengguna laporan keuangan dapat melihat perkembangan dan progress keuangan setiap periode dari entitas penyusun. Akuntansi akrual menggambarkan pengaruh transaksi dan peristiwa lain dan keadaan sumber daya pelaporan entitas ekonomi dan klaim pada periode di mana efek tersebut terjadi, meskipun penerimaan dan pembayaran kas terjadi pada periode yang berbeda. ${ }^{8}$

Banyaknya transaksi usaha berdasarkan kredit yang merupakan transaksi dengan orientasi jangka panjang. Akuntansi akrual bertujuan untuk memberi informasi mengenai konsekuensi kas akibat aktivitas transaksi dari suatu entitas secara cepat. Pada basis akrual, suatu penjualan kredit atau pendapatan segera dicatat saat terjadinya penjualan tersebut tanpa menunggu saat pelunasan, beban dan

8 Lam, Nelson,. Lau, Peter. 2014. Intermediate Financial Reporting : An IFRS Perspective, $2^{\text {nd }}$ ed. trj Taufik Arifin. Jakarta : Salemba Empat. hal. 24 . pembelian kredit segera dibukukan ketika terjadi dan diakui sebagai beban yang harus ditunaikan dimasa yang akan datang. Dengan diaplikasinya dasar akrual maka neraca dan laporan laba rugi lebih akurat menggambarkan posisi keuangan dan hasil usaha dari suatu entitas, ${ }^{9}$ karena dapat mengukur kapasistas sebuah entitas untuk menghasilkan kas.

Secara umum, akuntansi didasari atas upaya dalam memperoleh hasil dari sebuah transaksi ekonomi yang dilakukan entitas. Hasil tersebut dapat berupa laba atau rugi tergantung dengan jumlah pendapatan yang diperoleh dan jumlah biaya yang harus dikeluarkan, dalam hal ini tidak terdapat pembatasan terhadap waktu pendapatan dan biaya pada kondisi pendapatan yang telah diterima atau biaya yang telah dibayar. Akuntansi menekankan substansi suatu kegiatan atau transaksi yang menimbulkan biaya dan pendapatan, ${ }^{10}$ dengan demikian tidak terdapat secara eksplisit ketentuan mengenai keharusan sebuah transaksi diakui secara kas (Cash Basis).

Hal tersebut menjadi salah satu acuan penggunaan akuntansi berbasis akrual, dibandingkan basis kas. Di samping itu berdasarkan Statement of Financial Accounting Concept No. 1 menyatakan bahwa kelebihan dari akrual basis adalah pada kemampuannya untuk melihat peluang entitas dalam menghasilkan laba karena terindikasi dari informasi arus kas pada masa kini dan masa yang akan datang. Informasi kemampuan entitas dalam menjaga arus kas dianggap merupakan salah satu indikator kelangsungan usaha yang terjamin melalui cash flow yang

9 Kartikahadi, Hans dkk. 2016. Akuntansi Keuangan berdasarkan SAK berbasis IFRS. Jakarta : Ikatan Akuntan Indonesia. Hal. 52.

10 Suwadjono. 2010. Teori Akuntansi Perekayasaan Pelaporan Keuanga. Yogyakarta : BPFE. hal. 237. 
diperkirakan akan terjadi di masa yang akan datang, berbeda dengan kas basis yang menekankan aspek pencatatan dan pelaporan berdasarkan aliran real dari penerimaan dan pembayaran kas.

Basis akrual memiliki konsekuiensi pada pos-pos akuntansinya, yaitu pada pospos akruan (accrued) dan tangguhan (deffered). ${ }^{11}$ Akuntansi akrual terdiri atas dua prinsip dasar pengakuan pendapatan dan beban yang mengarahkan entitas untuk melihat kapan saatnya untuk mengakui pendapatan atau beban yang diperoleh, pendapatan dan beban akan direalisasikan saat terjadi aliran kas keuluar atau masuk. Akuntansi akrual dapat dibedakan menjadi akrual jangka panjang dan jangka pendek, pertama akrual jangka panjang (long term accrual) merupakan proses kapitalisasi aset terhadapat penangguhan biaya maupun pendapatan karena diharapkan manfaat yang dapat diperoleh pada masa yang akan datang, sedangkan kedua akrual jangka pendek (short term accrual) lebih mengacu kepada perbedaan waktu yang pendek antara laba dan arus kas, yang biasanya berasal dari persediaan dan transaksi kredit yang menimbulkan semua bentuk piutang dan kewajiban seperti debitor dan kreditor transaksi perdagangan, beban dibayar di muka dan penerimaan uang muka. ${ }^{12}$

Keunggulan dari konsep dasar akrual pada laporan keuangan adalah dari kemampuannya untuk memberikan informasi yang relevan dalam mengukur kapasitas suatu entitas dalam hal cash flow pada masa yang akan datang. Keunggulan dasar akrual dalam menyajikan informasi relevan atas kinerja dan kondisi keuangan suatu entitas dan untuk memprediksi arus kas masa depan yaitu : ${ }^{13}$

\footnotetext{
11 Ibid.

12 Subramanyam dan John J Wild. 2012. Financial Statement Analysis. terj Dewi Yanti. Jakarta :

Salemba Empat. hal. 99-100.

13 Ibid.
}

- Kinerja keuangan, pengakuan terhadap pendapatan dan biaya menghasilkan angka laba yang lebih unggul karena dengan pengakuan pendapatan telah memastikan bahwa pendapatan yang dihasilkan dalam suatu periode telah diakui, dan pengaitan beban yang dicatat pada suatu periode hanya beban yang terkait dengan pendapatan periode tersebut.

- Kondisi keuangan, akuntansi akrual menghasilkan neraca yang lebih merefleksikan secara akurat sumber daya yang tersedia bagi suatu entitas untuk menghasilkan arus kas di masa depan.

- Prediksi arus kas masa depan, laba akrual lebih unggul dalam memprediksi arus kas masa depan karena dua hal yaitu pertama melalui pengakuan pendapatan yang mencerminkan konsekuensi arus kas masa depan, kedua akuntansi akrual mengaitkan arus kas masuk dan keluar dengan lebih baik sepanjang waktu melalui proses pengaitan.

Penerapan dasar akrual pada akuntansi syariah.

Asumsi akuntansi syariah didasarkan pada pendekatan akrual dan kas. Dasar akrual yang dianut oleh akuntansi syariah terlihat pada penggunaan istilah tangguhan (deffered), hal tersebut terlihat pada transaksi-transaksi akuntansinya, baik pada transaksi jual beli, syirkah maupun sewa-menyewa. Ketentuan akuntansi akrual yang dilakukan pada tingkat keuntungan tertentu atas penyerahan aset yang disepakati sebagai bagian transaksi jual beli, syirkah maupun sewa. Asumsi berbasis akrual dalam konsep akuntansi syariah sebenarnya merupakan suatu praktik amanah dalam bertransaksi, keadaan dimana telah terjadi kesepakatan 
antara penjual dan pembeli dengan kondisi bahwa pembeli sepakat akan menunaikan kewajibannya di masa yang akan datang.

Pada entitas syariah seperti lembaga keuangan syariah penggunaan jenis akad akan menentukan jenis pencatatan transaksi akuntansi syariahnya. Ketika terjadi kesepakatan terhadap sebuah transaksi maka pencatatan yang dilakukan disesuaikan dengan akun yang terdapat pada pernyataan standar akuntansi keuangan syariah. Terdapat pemisahan transaksi tersebut menjadikan asumsi dasar akrual pada akuntansi syariah dapat diaplikasikan dengan tepat.

Terdapat perbedaan yang mendasar dalam perlakuan akuntansi secara akrual pada transaksi jual beli dengan transaksi syirkah. Pada sistem jual beli tingkat keuntungan atau yang dikenal dengan istilah margin ditentukan pada tingkat harga tertentu dan didapatkan secara flat atau tetap. Berbeda dengan pada sistem syirkah yang tingkat keuntunganya melalui bagi hasil diperoleh secara fluktuatif tergantung dengan pendapatan yang diperoleh sehingga penetapannya dilakukan melalui tingkat persen.

- Penerapan dasar akrual pada akad jual beli

Perlakukan akuntansi akrual pada transaksi jual beli berlaku pada akad murabah\}ah dan istis\}na, hal tersebut dikarenakan pada keduanya memungkinkan untuk terjadi penerimaan keuntungan di masa yang akan datang berbeda dengan akad salam yang menuntut penerimaan kas secara tunai dan lunas di awal transaksi. Pada akad murabahłah pengakuan keuntungan dapat dilakukan dengan tiga pendekatan yang berbeda yaitu pertama, pengakuan keutuntungan di awal yakni margin diakui pada saat penyerahan pesanan atau aset murabahlah kepada pihak pemesan, kedua pengakuan keuntungan secara proporsional yakni keuntungan ditangguhkan (tidak diakui) hingga pembayaran angsuran dari pihak pemesan dilakukan, ketiga pengakuan keuntungan pada akhir atau saat pelunasan keselutuhan piutang oleh pihak pemesan. Sedangkan untuk akad istis/na pengakuan keuntungan secara akrual hanya dilakukan dengan dua pendekatan yaitu secara proporsional (cicilan) atau sekaligus diakhir.

Hal tersebut dikarenakan sistem akad murabah\}ah barang atau aset pesanan diserahkan di awal dan sistem pembayaran di akhir, berbeda dengan akad istis\}na yang aset pesanan dapat diserahkan secara bertahap atau sekaligus diakhir dengan sistem pembayaran secara bertahap atau sekaligus diakhir juga.

- Penerapan dasar akrual pada akad syirkah

Perlakuan akuntansi akrual pada akad syirkah tidak sama dengan akad jual beli, pada akad syirkah penggunaan istilah keuntungan tangguhan dilakukan pada saat transaksi penyerahan aset modal non kas ${ }^{14}$ kepada mitra. Keuntungan tangguhan dipergunakan untuk mencatat nilai lebih yang timbul akibat penyerahan modal non kas dimana nilai wajarnya ${ }^{15}$

14 Pada transaksi syirkah baik transaski mudharabah maupun musyarakah modal yang disepakati dapat diserahkan dalam bentuk uang tunai (kas) atau dalam bentuk modal barang (modal non kas). Keberadaan modal non kas sebagai bentuk modal yang diserahkan dari pemilik modal kepada pelaku usaha memiliki konsekuensi adanya perbedaan nilai antara nilai tercatat dengan nilai wajar yang berlaku saat itu.

15 Nilai wajar merupakan nilai yang dipergunakan ketika mempertukarkan antara pihak-pihak yang berkeinginan, dengan dilandasi terhadap pengetahuan akan nilai barang tersebut yang berlaku asat itu. 
saat penyerahan lebih besar dari nilai tercatatnya. ${ }^{16}$ Pengakuan keuntungan tangguhan dilakukan amortisasi setiap periodenya di sesuaikan dengan jumlah atau lama periode yang disepakati dalam transaksi.

Perlakuan dasar akrual pada laporan keuangan lebih relevan dibandingkan dasar kas, karena dengan menerapkan pengakuan saat ini pada sistem penerimaan kas di masa yang akan datang akan memudahkan setiap pengguna laporan untuk mengukur kondisi keuangan dan kinerja. Kondisi tersebut akan menyebabkan terjadi kebergantungan terhadap nilai arus kas di masa yang akan datang. Padahal penilaian terhadap kehidupan perusahaan tidak selamanya disandarkan pada arus kas di masa yang akan datang, keberadaan arus kas di masa yang akan datang menunjukkan seberapa besar peluang laba yang akan diperoleh.

Kebergantungan terhadap arus kas di masa yang akan datang setidaknya memunculkan risiko seandainya arus kas tersebut tidak dapat terealisasi dengan sempurna. Pada akuntansi syariah sebagaimana yang telah dijelaskan sebelumnya pengakuan kuntungan tangguhan dipergunakan pada akad jual beli dan akad syirkah. Dari kedua akad tersebut potensi kerugian akibat kredit macet terdapat pada akad jual beli, dan untuk akad syirkah tidak terdapat potensi riil dari kerugian kecuali aset non kas dari barang tersebut tidak kembali. Pada akad syirkah tingkat keuntungan yang dtangguhkan disandarkan kepada selisih harga wajar dengan harga perolehan dari aset yang menjadi bagian modal transaksi syirkah. Dengan kata lain, arus kas dari pengeluaran aset syirkah telah dilakukan

16 Nilai tercatat merupakan nilai atau harga yang harus dikeluarkan pada saat memperoleh suatu barang, nilai tercatat biasa dikenal juga dengan nilai perolehan. saat pembelian aset tersebut dan keuntungan muncul seiring adanya selisih positif antara harga perolehan dengan harga wajar saat penyerahan aset syirkah. keuntungan tersebut akan diakui secara amortisasi per periode sesuai dengan lama periode akad syirkah yang disepakati. Hal tersebut berbeda dengan akad jual beli murabah\}ah yang pengakuan keuntungan tangguhannya disandarkan kepada arus kas yang belum diterima.

Penggunaan cadangan kerugian tidak selamanya dapat menutup kerugian yang mungkin akan ditimbulkan akibat tidak terealisasinya arus kas tersebut. Pada akad transaksi murabahjah akun cadangan kerugian dibentuk sebagai antisipasi jika terjadi kredit macet pada piutang murabah\}ah. Risiko kredit macet dapat menyebabkan tidak terealisasinya arus kas keuntungan yang telah diperkirakan akan diperoleh pada awal transaksi. Solusinya adalah dibentuknya cadangan kerugian atau meminta jaminan atas transaksi yang telah disepakati. Piutang murabah \}ah itu sendiri muncul dari transaksi penyerahan barang kepada pemesan, sebagai bentuk hak atas kas dari konsumen yang telah membeli aset dengan cara kredit.

Pengakuan keuntungan atas transaksi murabahłah akan dipilih sesuai dengan risiko macet dari arus kas piutang dan beban yang akan muncul, ketika risiko diperkirakan relatif kecil maka pengakuan keuntungan akan dilakukan di awal sedang untuk risiko yang relatif sedang pengakuan dilakukan secara proporsional dan untuk risiko relatif besar maka pengakuan keuntungan dilakukan saat seluruh piutang berhasil ditagih. Hal tersebut berlaku juga pada akad istisjna namun yang membedakan akad istis \}na hanya memiliki dua pendekatan yaitu secara proporsional (cicilan) atau sekaligus diakhir.

Seandainya dilihat lebih lanjut, sebenarnya peluang kerugian terbesar 
berada pada metode pengakuan keuntungan di awal, pertimbangan survey dan analisis yang matang sebenarnya mampu menjawab pilihan tersebut. Namun jika mengacu kepada prinsip kehati-hatian hal tersebut seharusnya ditinggalkan, dalam hal ini risiko hanya terdapat pada akad transaksi murabah\}ah karena pada akad istis\}na tidak terdapat metode pengakuan keuntungan di awal. Risiko pembiayaan atau risiko kredit merupakan hal yang sering terjadi terkait dengan macetnya arus kas angsuran dari nasabah. Risiko pembiayaan itu mengacu kepada potensi kerugian yang akan dihadapi bank ketika pembiayaan yang diberikannya macet, dalam hal ini debitur mengalami kondisi tidak mampu memenuhi kewajiban pengembalian modal dari perbankan, termasuk porsi keuntungan yang telah diperjanjikan di awal yang seharusnya dapat diperoleh perbankan. ${ }^{17}$

Istilah risiko yang sering muncul dalam hal ini adalah risiko gagal bayar baik yang terjadi akibat faktor internal maupun karena faktor eksternal. Risiko gagal bayar sebenarnya dapat diatasi melalui proses survey dan pengkajian yang mendalam terhadap sebuah akad transaksi murabah\}ah yang akan dijalankan. Proses tersebut setidaknya dapat mengklasifikasikan beberapa pembiayaan berdasar akad murabah\}ah yang berpotensi macet dan lancar. Klasifikasi dari risiko itu sendiri terdiri dari faktor internal yaitu kelalaian dari pihak nasabah dan faktor eksternal sperti force majeur yang tidak diinginkan. Faktor kelalaian dapat diatasi melalui pengawasan dan peninjauan secara berkesinambungan terhadap nasabah, sedangkan faktor ekstenal merupakan sesuatu yang tidak dapat diprediksi dengan mudah, meskipun untuk saat ini dapat diperkirakan melalui beberapa metode

17 Wahyudi, Imam dkk. 2013. Manajemen Risiko Bank Islam. Jakarta : Salemba Empat. hal. 90. modern namun masih tetap terdapat peluang untuk tidak teratasi. Hal tersebut dikarenakan force majeur termasuk merupakan kejadian di luar nalar dari manusia.

Dampak yang mungkin terjadi terkait dengan pihak stakehloder merupakan hal yang harus dihindari akibat gagal bayar tersebut. Risiko pada pembiayaan murabah\}ah adalah adanya kemungkinan risiko tidak bersaingnya bagi hasil kepada dana pihak ketiga. ${ }^{18}$ Kondisi tersebut akan berpengaruh kepada risikorisiko lainnya seperti sebuah efek domino, ketika kerdit pembiayaan macet maka risiko likuiditas, risiko profitabilitas dan risiko reputasi akan ikut muncul seiring dengan terkendalanya aliran kas. Teknik pengendalian risiko menjelaskan bahwa terdapat beberapa pilihan dalam meminimalisir sebuah resiko yaitu dengan penghindaran risiko ( Risk avoidance), pengendalian risiko (Risk control), penanggungan atau penahanan risiko (Risk retention) dan pengalihan risiko (Risk transfer). ${ }^{19}$

Pilihan dalam memanajemen risko tersebut dilakukan berdasarkan tingkat kesulitan risiko yang ada, ketika risiko tersebut dapat ditiadakan dengan cara menghindarinya maka pilihan yang tepat untuk risiko tersebu adalah penghindaran risiko. Kasus yang terdapat dalam pengakuan keuntungan pada akuntansi murabah\}ah memungkinkan untuk menghindari risiko tidak lancarnya arus kas keuntungan akibat kredit macet, pilihan yang tepat dalam pengakuan keuntungan pada transaksi piutang murabahjah adalah dengan pengakuan secara proporsional dan pengakuan diakhir saat pelunanasan

18 Rustam, Bambang Rianto. 2013. Manajemen Risiko Perbankan Syariah di Indonesia. Jakarta : Salemba Empat. hal. 56.

19 Hanafi, Mamduh M. 2012. Manajemen Risiko. Yogyakarta : UPP STIM YKPN. hal. 246. 
piutang. Untuk kedua pengakuan keuntungan tersebut tetap mempergunakan metode akuntansi dasar akrual, hanya yang membedakan penyesuaian terhadap pengakuan aliran kas disesuaikan dengan masuknya aliran kas, sedangkan untuk pengakuan pada awal transaksi murabahlah tidak memperhatikan aliran kas karena telah diasumsikan bahwa aliran kas akan berjalan dengan baik.

Risiko yang dapat terjadi akibat pengakuan di awal pada laporan keuangan adalah ketika kredit terjadi kemacetan sehingga keuntungan yang telah diakui tidak dapat dipertanggung jawabkan kepada pihak yang berkepentingan. Efek yang timbul tersebut akan berdampak secara tidak baik pada asumsi kelangsungan usaha entitas. Pilihan yang tidak berisiko pada laporan keuangan lembaga keuangan syariah adalah penggunaan pengakuan keuntungan murabahjah tangguhan secara proporsional dan pengakuan keuntungan pada akhir akad (saat pelunasan piutang murabah\}ah). Keduanya menggunakan asumsi akrual namun pengakuan dilakukan saat aliran kas masuk.

\section{Kesimpulan}

Penggunaan asusmi dasar akrual merupakan bagian dari kesatuan yang dianut dalam penyusunan laporan keuangan pada lembaga keuangan syariah. Penggunaan asumsi akrual dilakukan pada pengakuan keuntungan pada akad jual beli, syirkah dan sewa. Namun risiko yang muncul dari metode akrual terdapat pada transaksi murabah\}ah, karena pada akad murabah\}ah terdapat pengakuan keuntungan atas arus kas yang belum dapat dipastikan keberadaannya.

Pada akad murabahłah terdapat metode pengakuan keuntungan di awal atas arus kas yang belum masuk. Meskipun dalam penentuan kebijakan transaksi murabah\}ah tersebut dilakukan survey dan uji untuk menjamin adanya aliran kas masuk, namun konsekuensi yang diterima tetap terdapat kemungkinan untuk tidak dapat dihindari. Adanya faktor eksternal dari penyebab kredit macet yang dapat menyebabkan peluang aliran kas tidak lancar.

Dari sini dapat disimpulkan bahwa bagi lembaga keuangan syariah yang mempergunakan akad transaksi murabah\}ah sebaiknya menghindari pengakuan keuntungan di awal terhadap piutang murabah\}ah, dan lebih dianjurkan untuk memilih mempergunakan metode pengakuan keuntungan secara proporsional atau pengakuan di akhir akad.

\section{Daftar Pustaka}

Hanafi, Mamduh M. 2012. Manajemen Risiko. Yogyakarta : UPP STIM YKPN.

Kartikahadi, Hans dkk. 2016. Akuntansi Keuangan berdasarkan SAK berbasis IFRS. Jakarta : Ikatan Akuntan Indonesia.

Lam, Nelson,. Lau, Peter. 2014. Intermediate Financial Reporting : An IFRS Perspective, $2^{\text {nd }}$ ed. trj Taufik Arifin. Jakarta : Salemba Empat.

Nurhayati, Sri. Wasilah. 2013. Akuntansi Syariah di Indonesi. Jakarta : Salemba Empat.

Rustam, Bambang Rianto. 2013. Manajemen Risiko Perbankan Syariah di Indonesia. Jakarta : Salemba Empat.

Salman, Kautsar Riza. 2012. Akuntansi Perbankan Syariah berbasis PSAK Syariah. Padang : Akademia. 
Subramanyam dan John J Wild. 2012. Financial Statement Analysis. terj Dewi Yanti. Jakarta : Salemba Empat.

Wahyudi, Imam dkk. 2013. Manajemen Risiko Bank Islam. Jakarta : Salemba Empat.

Suwadjono. 2010. Teori Akuntansi Perekayasaan Pelaporan Keuanga. Yogyakarta : BPFE.

Triyuwono, Iwan. 2012. Akuntansi Syariah Perspektif, Metodologi, dan Teori, Jakarta : PT. Raja Grafindo Persada. 